\title{
Process Discovery untuk Streaming Event log Menggunakan Model Markov Tersembunyi
}

\author{
Kelly R. Sungkono, Riyanarto Sarno, dan Abdul Munif \\ Jurusan Teknik Informatika, Fakultas Teknologi Informasi, Institut Teknologi Sepuluh Nopember (ITS) \\ Jl. Arief Rahman Hakim, Surabaya 60111 Indonesia \\ e-mail: riyanarto@if.its.ac.id
}

\begin{abstract}
Abstrak-Process discovery adalah teknik penggalian model proses dari rangkaian aktivitas yang tercatat dalam event log. Saat ini, sistem informasi menghasilkan streaming event log dimana Online Heuristic Miner adalah algoritma process discovery yang mampu menghasilkan model proses dari streaming event log. Algoritma Online Heuristic Miner memiliki kelemahan yaitu ketidakmampuan mengatasi incomplete trace. Incomplete trace adalah rangkaian aktivitas pada event log yang terpotong di bagian awal ataupun di bagian akhir. Incomplete trace mengakibatkan proses tidak dapat ditampilkan secara utuh dalam model proses. Algoritma yang memanfaatkan Model Markov Tersembunyi digunakan untuk membentuk model proses yang dapat menangani incomplete trace. Algoritma yang memanfaatkan Model Markov Tersembunyi terdiri atas gabungan dari metode pembentukan model proses serta metode yang dimodifikasi. Metode yang dimodifikasi adalah metode Baum-Welch, Backward serta Viterbi. Metode Backward dan Viterbi yang dimodifikasi digunakan untuk memperbaiki incomplete trace sedangkan metode Baum-welch yang dimodifikasi dan metode pembentukan model proses digunakan untuk membangun model proses dari Model Markov Tersembunyi. Hasil uji coba menunjukkan bahwa dengan adanya perbaikan incomplete trace, nilai kualitas dari sisi fitness, presisi, generalisasi, dan simplicity model proses dari algoritma yang memanfaatkan Model Markov Tersembunyi lebih tinggi dibandingkan model proses dari algoritma Online Heuristic Miner.
\end{abstract}

Kata Kunci-Incomplete Trace, Model Markov Tersembunyi, Process Discovery, Streaming Event log.

\section{PENDAHULUAN}

$\mathrm{T}$ EKNIK penggalian model proses bisnis dari beberapa rangkaian aktivitas yang tercatat pada event log adalah process discovery [1]. Model proses bisnis memiliki dua manfaat utama, yaitu sebagai alat bantu untuk menjelaskan proses yang terjadi pada sistem serta sebagai modal utama dalam menganalisa permasalahan terkait pengaturan rangkaian aktivitas.

Faktanya, sistem infomasi saat ini menghasilkan streaming event log dimana keseluruhan event log tidak dapat tersimpan di dalam sistem [2]. Selain itu, adanya kemungkinan pertambahan aktivitas di tengah-tengah proses sehingga model proses diharuskan mampu menampilkan pertambahan aktivitas tersebut.

Online Heuristic Miner adalah algoritma process discovery untuk streaming event log dimana algoritma ini mampu beradaptasi dengan pertambahan aktivitas di tengah proses [2]. Kelemahan dari Online Heuristic Miner adalah kemunculan incomplete trace pada streaming event log. Incomplete trace adalah rangkaian aktivitas (trace) pada event log yang terpotong di bagian awal ataupun di bagian akhir trace. Incomplete trace dapat mengakibatkan model proses bisnis tidak akurat dikarenakan adanya aktivitas yang tidak terekam pada saat process discovery.

Oleh karena itu, algoritma yang memanfaatkan Model Markov Tersembunyi digunakan untuk membangun model proses yang mampu mengatasi kemunculan incomplete trace. Model Markov Tersembunyi telah digunakan di berbagai bidang untuk peramalan, seperti speech recognition [3], gene prediction [4] ataupun stock market forecasting [5]. Penelitian [6] telah memanfaatkan Model Markov Tersembunyi dalam process discovery. Akan tetapi, process discovery pada penelitian tersebut belum menggunakan data streaming event $\log$, melainkan menggunakan data event log tetap.

Algoritma yang memanfaatkan Model Markov Tersembunyi digunakan untuk process discovery menggunakan data streaming event log dimana process discovery ini dapat menangani incomplete trace. Algoritma yang memanfaatkan Model Markov Tersembunyi terdiri dari metode pembentukan model proses serta metode yang dimodifikasi. Metode yang dimodifikasi adalah metode Baum-welch [7], metode Viterbi [7] dan metode Backward [7]. Metode Baum-welch digunakan untuk menentukan probabilitas pada Model Markov Tersembunyi, metode Viterbi digunakan untuk memperbaiki incomplete trace akibat terpotongnya aktivitas di bagian akhir dan metode Backward digunakan untuk memperbaiki incomplete trace akibat terpotongnya aktivitas di bagian awal. Pemodifikasian metode Viterbi maupun metode Backward digunakan untuk menanggulangi aktivitas baru yang belum terbentuk di Model Markov Tersembunyi dan pemodifikasian metode Baum-welch digunakan untuk mengatur kelompok observer yang bergantung pada state Model Markov Tersembunyi. Sedangkan, metode pembentukan model proses digunakan untuk menentukan relasi antar aktivitas sebagai bahan pembentukan model proses. Relasi antar aktivitas terdiri dari empat macam, yaitu relasi XOR, OR, AND dan Sequence. Uji coba akan dilakukan sebanyak tiga kali, dimana perbedaan dari ketiga uji coba tersebut adalah jangka waktu antar pembentukan model proses. Pengujian dimaksudkan untuk memunculkan beragam kemunculan incomplete trace pada streaming event log. Hasil uji coba menunjukkan bahwa nilai kualitas model proses dari algoritma yang memanfaatkan Model Markov Tersembunyi lebih tinggi dibandingkan model proses dari algoritma Online Heuristic Miner. Kualitas model 
proses diukur berdasarkan 4 sisi yaitu fitness [8], presisi [1], generalisasi [9] dan simplicity [9].

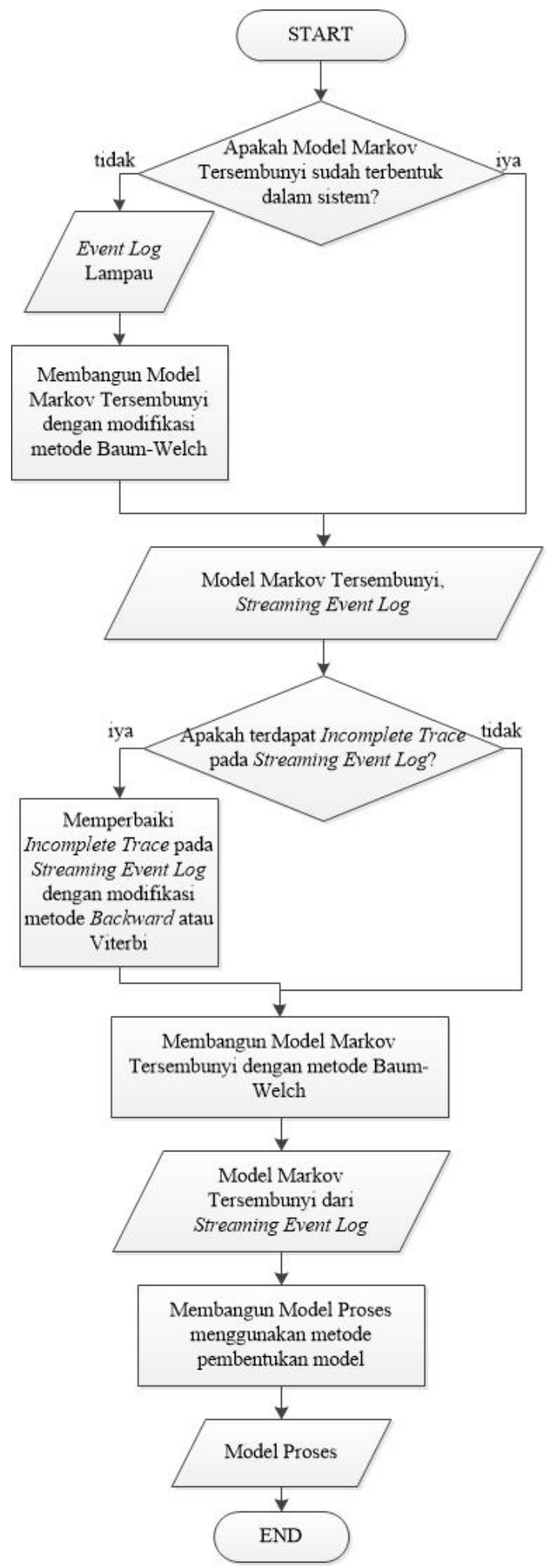

Gambar 1. Alur Proses dari Algoritma yang memanfaatkan Model Markov Tersembunyi

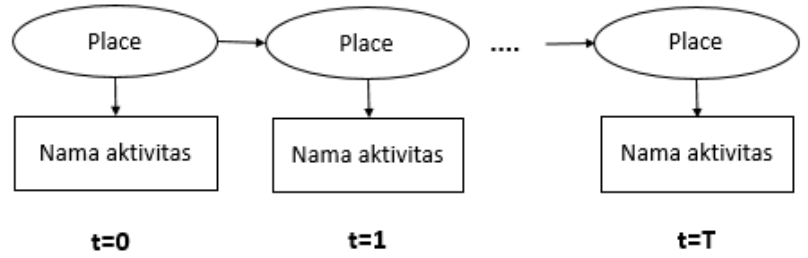

Gambar 2. Gambaran Model Markov Tersembunyi

Tabel 1.

Metode Baum-welch yang dimodifikasi

\begin{tabular}{|c|c|}
\hline Bagian & Penjelasan \\
\hline Masukan Metode & Event log lampau. \\
\hline $\begin{array}{l}\text { Keluaran Metode } \\
\text { Alur Metode }\end{array}$ & $\begin{array}{l}\text { Model Markov Tersembunyi dari event log lampau. } \\
\text { 1. Pengelompokkan aktivitas sebagai observer } \\
\text { dimana aktivitas yang mempunyai relasi paralel } \\
\text { dengan aktivitas lain dimasukkan dalam } \\
\text { kelompok yang sama. } \\
\text { 2. Jumlah state adalah jumlah kelompok observer } \\
\text { dimana observer dalam satu kelompok } \\
\text { bergantung pada state yang sama. } \\
\text { 3. Pembangunan Model Markov Tersembunyi } \\
\text { menggunakan metode Baum-welch [11]. }\end{array}$ \\
\hline
\end{tabular}

\section{METODE PENELITIAN}

\section{A. Gambaran Umum Metode Penelitian}

Metode untuk pembentukan model proses dari streaming event log adalah algoritma yang memanfaatkan Model Markov Tersembunyi, seperti yang dirunjukkan pada Gambar 1.

Algoritma yang memanfaatkan Model Markov Tersembunyi menggunakan event log lampau dan streaming event log sebagai masukan. Event log lampau adalah event log tetap, dimana seluruh trace (rangkaian aktivitas) sudah tersimpan secara keseluruhan dalam sistem. Sedangkan streaming event $\log$ adalah event $\log$ yang berjalan sesuai waktu eksekusi aktivitas pada event log tersebut.

\section{B. Membangun Model Markov Tersembunyi berdasarkan Event log Lampau}

Membangun Model Markov Tersembunyi berdasarkan event log lampau merupakan proses pertama dari algoritma yang memanfaatkan Model Markov Tersembunyi. Gambar 2 menunjukkan gambaran Model Markov Tersembunyi yang digunakan. Bentuk Model Markov Tersembunyi yang digunakan didasarkan pada model Petri net, dimana state pada Model Markov Tersembunyi merupakan place sedangkan observer pada Model Markov Tersembunyi merupakan nama aktivitas. Setiap observer bergantung pada state yang sama apabila observer tersebut memiliki relasi paralel. Penentuan relasi paralel mengacu pada metode Process discovery based on Activity Lifespan [10].

Metode Process discovery based on Activity Lifespan [10] mengemukakan bahwa suatu aktivitas memiliki relasi paralel dengan aktivitas lain apabila waktu mulai aktivitas tersebut terjadi sebelum waktu selesai aktivitas lain. Sesuai dengan metode Process Discovery based on Activity Lifespan, maka event log yang digunakan, baik event log lampau maupun streaming event log, menggunakan pencatatan waktu ganda (waktu mulai dan waktu selesai suatu aktivitas). 
Tabel 2.

Pseudo-code metode Backward dan Viterbi yang dimodifikasi

\begin{tabular}{|c|c|}
\hline Bagian & Penjelasan \\
\hline $\begin{array}{l}\text { Masukan Metode } \\
\text { Keluaran Metode }\end{array}$ & $\begin{array}{l}A_{L}, B_{L}, \pi_{L} \text {, seq_stream (streaming event } \log \text { ). } \\
\text { seq_repair (streaming event log yang telah } \\
\text { diperbaiki). }\end{array}$ \\
\hline Alur Metode & 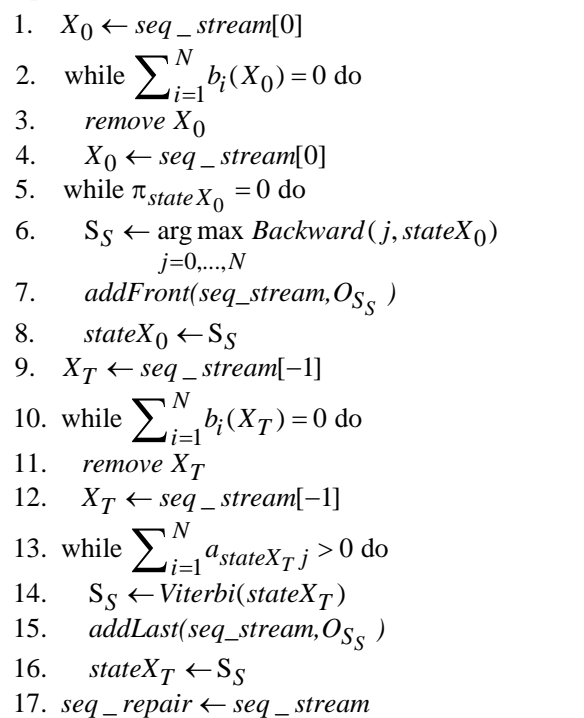 \\
\hline
\end{tabular}

\begin{tabular}{|c|c|}
\hline \multicolumn{2}{|l|}{ dimana: } \\
\hline$\pi_{L}$ & $\begin{array}{l}\text { : vektor probabilitas state sebagai state } \\
\text { awal dari event log lampau. }\end{array}$ \\
\hline$a_{\text {stateX }} j$ & $\begin{array}{l}\text { : nilai probabilitas transisi dari state yang } \\
\text { memiliki observer } X_{T} \text { ke state } j \text {. }\end{array}$ \\
\hline addFront(seq_stream, $O_{S_{S}}$ ) & $\begin{array}{l}\text { : observer dari state } S \text { ditambahkan pada } \\
\text { bagian pertama dari incomplete trace. }\end{array}$ \\
\hline$A_{L}$ & $\begin{array}{l}\text { matrik probabilitas transisi state dari } \\
\text { event log lampau. }\end{array}$ \\
\hline $\operatorname{addLast}\left(\right.$ seq_stream, $\left.O_{S_{S}}\right)$ & $\begin{array}{l}\text { observer dari state } S \text { ditambahkan pada } \\
\text { bagian akhir dari incomplete trace. }\end{array}$ \\
\hline$b_{i}\left(X_{0}\right)$ & $\begin{array}{l}\text { : nilai probabilitas observer } X_{0} \text { terhadap } \\
\text { state } i \text {. }\end{array}$ \\
\hline$B_{L}$ & $\begin{array}{l}\text { matrik probabilitas observer dari event } \\
\text { log lampau. }\end{array}$ \\
\hline $\operatorname{Backward}\left(j\right.$, state $\left._{0}\right)$ & $\begin{array}{l}\text { : nilai metode } \text { Backward [7] dari state } j \\
\text { dimana state } X_{0} \text { merupakan state yang } \\
\text { terjadi setelah state } j \text {. }\end{array}$ \\
\hline$N$ & : jumlah state pada $A_{L}$ \\
\hline seq_repair & : hasil perbaikan incomplete trace. \\
\hline seq_stream $[0]$ & : aktivitas pertama pada incomplete trace. \\
\hline seq_stream $[-1]$ & : aktivitas terakhir pada incomplete trace. \\
\hline$\pi_{\text {state } X_{0}}$ & $\begin{array}{l}\text { : nilai probabilitas state yang memiliki } \\
\text { observer } X_{0} \text { sebagai state awal. }\end{array}$ \\
\hline $\operatorname{Viterbi}\left(\right.$ stateX $\left._{T}\right)$ & $\begin{array}{l}\text { hasil dari metode Viterbi berupa state } \\
\text { dimana stateX } X_{T} \text { merupakan state yang } \\
\text { terjadi sebelum hasil metode Viterbi } \\
\text { [11]. }\end{array}$ \\
\hline$X_{0}$ & $\begin{array}{l}\text { nama aktivitas awal pada trace di event } \\
\log .\end{array}$ \\
\hline$X_{T}$ & $\begin{array}{l}\text { : nama aktivitas akhir pada trace di event } \\
\text { log. }\end{array}$ \\
\hline
\end{tabular}

Tabel 3.

Pseudo-code Pembangunan Model Markov Tersembunyi berdasarkan Streaming Event log

\begin{tabular}{c|c} 
& Streaming Event log \\
\hline \hline Bagian & Penjelasan \\
\hline Masukan Metode & $A_{L}, B_{L}, \pi_{L}$, seq_repair.
\end{tabular}

Keluaran Metode

Alur Metode

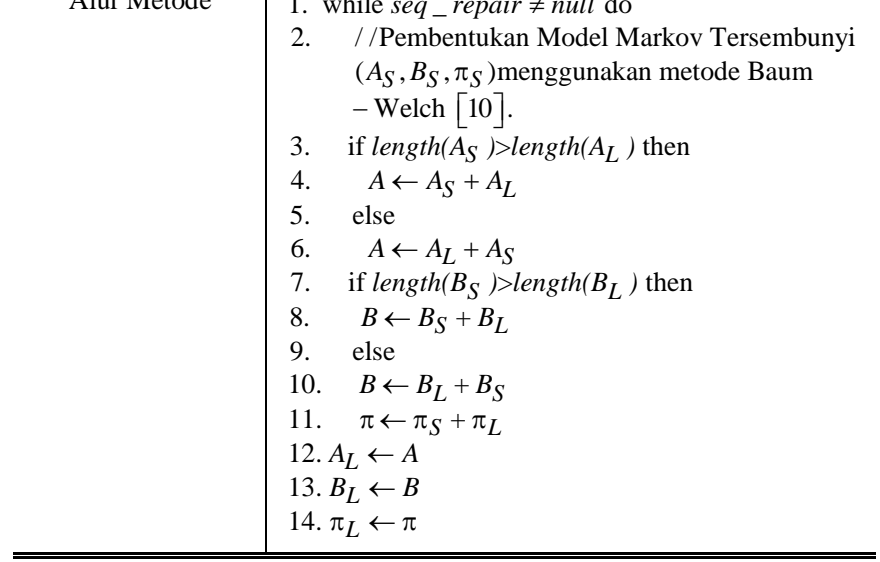

Model Markov Tersembunyi dari Streaming Event $\log \left(A_{S}, B_{S}, \pi_{S}\right)$ dan Model Markov Tersembunyi dari Event log Lampau $\left(A_{L}, B_{L}, \pi_{L}\right)$.

1. while seq_repair $\neq$ null do dimana:

$\pi_{L} \quad$ : vektor probabilitas state sebagai state awal dari event log lampau.

$\pi_{S} \quad:$ vektor probabilitas state sebagai state awal dari streaming event log.

$A_{L} \quad: \quad$ matrik probabilitas transisi state dari event log lampau.

$A_{S} \quad:$ matrik probabilitas transisi state dari streaming event log.

$B_{L} \quad$ : matrik probabilitas observer dari event log lampau.

$B_{S} \quad:$ matrik probabilitas observer dari streaming event log.

seq_repair : rangkaian observer pada streaming event log yang mengalami perbaikan apabila terdapat incomplete trace.

Pembangunan Model Markov Tersembunyi berdasarkan event log lampau menggunakan metode Baum-welch yang dimodifikasi. Modifikasi yang dilakukan adalah penambahan ketentuan kebergantungan observer terhadap state pada Model Markov Tersembunyi berdasarkan metode Process discovery based on Activity Lifespan sebelum metode Baum-welch dijalankan. Alur Modifikasi Metode Baum-welch dipaparkan pada Tabel 1.

\section{Memperbaiki Incomplete Trace pada Streaming Event log}

Memperbaiki incomplete trace merupakan proses kedua dari alur algoritma yang memanfaatkan Model Markov Tersembunyi. Metode yang digunakan adalah modifikasi dari metode Backward [7] dan metode Viterbi [11]. Tabel 2 menunjukkan modifikasi dari metode Backward dan metode Viterbi.

Apabila incomplete trace terjadi diakibatkan terpotongnya aktivitas di bagian awal, maka menggunakan metode Backward yang dimodifikasi (alur pseudo-code baris 1-8). Sedangkan apabila incomplete trace terjadi akibat terpotongnya aktivitas di bagian akhir, maka menggunakan metode Viterbi yang dimodifikasi (alur pseudo-code 9-16). Pemodifikasian baik pada metode Backward mapupun Viterbi dilakukan dengan menambahkan aturan untuk menanggulangi aktivitas baru di tengah-tengah proses. Pemodifikasian dapat dilihat pada alur pseudo-code baris 2-4 dan baris 10-12 pada Tabel 2 . 
Tabel 4.

Pseudo-code Penentuan Relasi

\begin{tabular}{|c|c|}
\hline Bagian & Penjelasan \\
\hline $\begin{array}{c}\text { Masukan } \\
\text { Metode } \\
\text { Keluaran } \\
\text { Metode } \\
\text { Alur Metode }\end{array}$ & 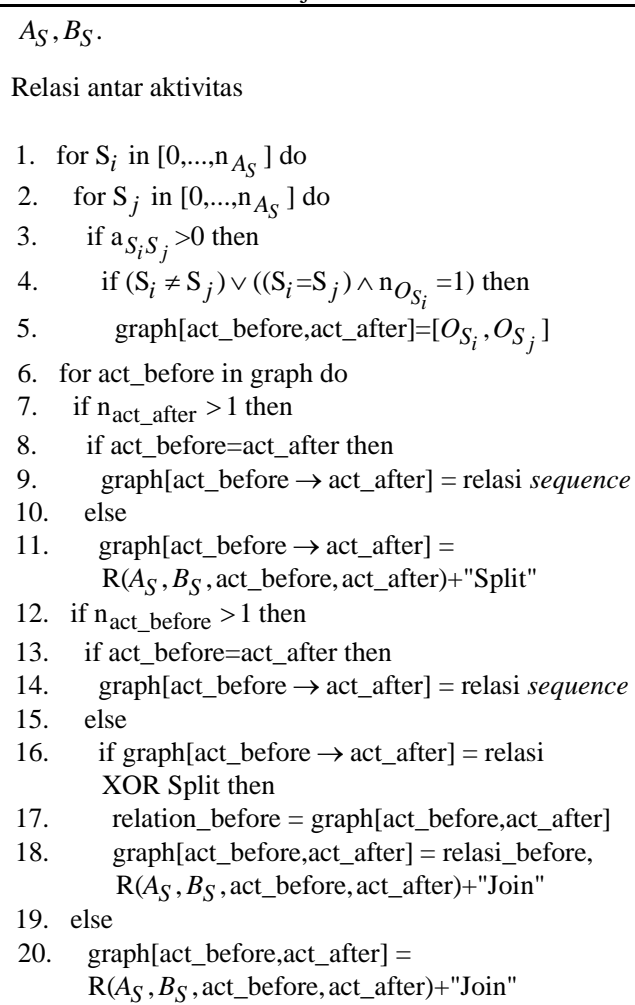 \\
\hline
\end{tabular}

\begin{tabular}{|c|c|}
\hline $\mathrm{a}_{S_{i}} S_{j}$ & : nilai probabilitas transisi state $\mathrm{S}_{i}$ ke state $\mathrm{S}_{j}$. \\
\hline$A_{S}$ & $\begin{array}{l}\text { : matrik probabilitas transisi state dari streaming } \\
\text { event log. }\end{array}$ \\
\hline$B_{S}$ & $\begin{array}{l}\text { : matrik probabilitas observer dari streaming event } \\
\log .\end{array}$ \\
\hline $\begin{array}{l}\text { graph[act_before, } \\
\text { act_after] }\end{array}$ & $\begin{array}{l}\text { : penampung aktivitas awal dan aktivitas akhir } \\
\text { untuk penentuan relasi. }\end{array}$ \\
\hline $\begin{array}{l}\text { graph[act_before } \\
\rightarrow \text { act_after] }\end{array}$ & $\begin{array}{l}\text { : penampung relasi antara aktivitas awal menuju } \\
\text { aktivitas akhir. }\end{array}$ \\
\hline $\mathrm{n}_{\text {act_after }}$ & $\begin{array}{l}\text { : jumlah aktivitas akhir untuk pembentukan suatu } \\
\text { relasi. }\end{array}$ \\
\hline $\mathrm{n}_{\text {act_before }}$ & $\begin{array}{l}\text { : jumlah aktivitas awal untuk pembentukan suatu } \\
\text { relasi. }\end{array}$ \\
\hline $\mathrm{n}_{A_{S}}$ & : jumlah state pada $A_{S}$. \\
\hline $\mathrm{n}_{O_{S_{i}}}$ & : jumlah observer yang bergantung pada state $S_{i}$. \\
\hline$O_{S_{i}}$ & $\begin{array}{l}\text { : kumpulan observer yang bergantung pada state } \\
\mathrm{S}_{i} \text {. }\end{array}$ \\
\hline $\begin{array}{l}\mathrm{R}\left(A_{S}, B_{S}, \text { act_before, }\right. \\
\text { act_after })\end{array}$ & $\begin{array}{l}\text { : fungsi untuk memanggil pseudo-code Penentuan } \\
\text { Relasi XOR, OR, AND, dan Sequence. }\end{array}$ \\
\hline
\end{tabular}

Tabel 5.

Pseudo-code Penentuan Relasi XOR, OR, AND, dan Sequence

\begin{tabular}{c|l}
\hline \hline Bagian & \multicolumn{1}{c}{ Penjelasan } \\
\hline Masukan Metode & $\begin{array}{c}A_{S}, B_{S}, \text { act_before, act_after } \\
\text { relation }\end{array}$
\end{tabular}

$$
\begin{aligned}
& \begin{array}{l|l}
\text { Alur Metode } & \text { 1. } \mathrm{i} \leftarrow \mathrm{S}_{\text {act_before }}
\end{array} \\
& \text { 2. } \mathrm{j} \leftarrow \mathrm{S}_{\text {act_after }} \\
& \text { 3. if }\left(\mathrm{n}_{\mathrm{i}}=1\right) \vee\left(\mathrm{n}_{\mathrm{j}}=1\right) \text { then } \\
& \text { 4. if }\left(\mathrm{n}_{\mathrm{i}}=1 \wedge \mathrm{n}_{\mathrm{j} \rightarrow}>1\right) \vee\left(\mathrm{n}_{\mathrm{j}}=1 \wedge \mathrm{n}_{\mathrm{i} \rightarrow}>1\right) \text { then } \\
& \text { 5. relation }=\text { relasi } \mathrm{XOR} \\
& \text { 6. else } \\
& \text { 7. graph[act_before } \rightarrow \text { act_after] }=\text { relasi sequence } \\
& \text { 8. else } \\
& \text { 9. //menghitung } \mathrm{RM}(\mathrm{i} \rightarrow \mathrm{j}) \text { dan avgPP sesuai (1) } \\
& \text { dan (2) } \\
& \text { 10. if } \mathrm{RM}(\mathrm{i} \rightarrow \mathrm{j}) \geq \operatorname{avgPP} \text { then } \\
& \text { 11. relation }=\text { relasi } \mathrm{AND} \\
& \text { 12. else } \\
& \text { 13. } \text { relation }=\text { relasi } \mathrm{OR} \\
& \text { dimana: } \\
& A_{S} \\
& B_{S} \\
& \text { graph[act_before } \\
& \rightarrow \text { act_after] } \\
& \mathrm{n}_{\mathrm{j} \rightarrow} \\
& \text { relation } \\
& \text { Sact_before }
\end{aligned}
$$

D. Membangun Model Markov Tersembunyi berdasarkan Streaming Event log

Membangun Model Markov Tersembunyi berdasarkan Streaming Event Log merupakan proses ketiga dari alur algoritma yang memanfaatkan Model Markov Tersembunyi. Streaming event log yang digunakan adalah streaming event log yang sudah mengalami perbaikan apabila streaming event log tersebut memiliki incomplete trace. Model Markov ini akan digunakan untuk membangun model proses.

Pembangunan Model Markov Tersembunyi berdasarkan streaming event log menggunakan metode Baum-welch dengan tambahan aturan untuk memperbaharui Model Markov Tersembunyi dari event log lampau yang digunakan untuk streaming event log selanjutnya. Tambahan aturan dilakukan dengan cara menggabungkan Model Markov Tersembunyi dari event log lampau dengan Model Markov Tersembunyi dari streaming event log. Aturan dapat dilihat pada alur pseudo-code Pembangunan Model Markov Tersembuyi baris 3-14. Pseudocode tersebut dipaparkan pada Tabel 3.

\section{E. Membangun Model Proses menggunakan Metode Pembentukan Model Proses}

Penelitian mengajukan metode pembentukan model proses yang digunakan untuk membangun model proses. Metode pembentukan model proses memanfaatkan Model Markov Tersembunyi dari streaming event log. Metode ini dibagi ke dalam dua pseudo-code yaitu pseudo-code Penentuan Relasi Aktivitas dan pseudo-code Penentuan Relasi XOR, OR, AND, dan Sequence. Kedua pseudo-code tersebut dipaparkan pada Tabel 4 dan Tabel 5. 


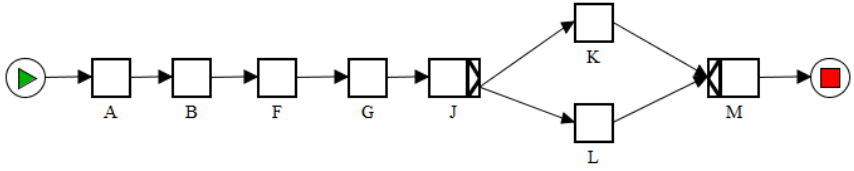

Gambar 3. Model Proses dari Event log Lampau

Pseudo-code Penentuan Relasi merupakan inti dari metode Pembentukan Model Proses, dimana alur pseudo-code baris 13 merupakan penentuan aktivitas yang berelasi dan alur pseudocode baris 4-20 merupakan penentuan relasi antar aktivitas. Penambahan kata "Split" seperti pada pseudo-code baris 11 menunjukkan bahwa aktivitas pilihan termasuk dalam aktivitas akhir suatu relasi. Sebaliknya, kata "Join" pada pseudo-code baris 18 dan 20 menunjukkan bahwa aktivitas pilihan termasuk dalam aktivitas awal suatu relasi.

Penentuan relasi menggunakan pseudo-code Penentuan Relasi XOR, OR, AND dan Sequence. Alur pseudo-code baris 3-5 merupakan ketentuan pengunaan relasi XOR dan alur psudo-code baris 3-7 merupakan ketentuan penggunaan relasi sequence. Ketentuan penggunaan relasi OR dan AND diatur pada alur pseudo-code baris 8-13 dimana melibatkan (1) dan (2).

$$
\begin{gathered}
\operatorname{RM}(i \rightarrow j)=\frac{a_{i i}}{a_{i j}} \times \frac{1}{n_{O_{i}}} \\
\operatorname{avgPP}=\frac{\sum_{i=0}^{n_{A}} \sum_{j=0}^{n_{A}} a_{i j}}{n_{a_{i j}}}
\end{gathered}
$$

Keterangan pada (1) dan (2):

$a_{i i} \quad$ :nilai probabilitas transisi state $i$ ke state itu sendiri.

$a_{i j} \quad$ : nilai probabilitas transisi state $i$ ke state $j\left(a_{i j}\right)$ dengan syarat nilai $a_{i j}$ lebih dari 0 .

$n_{A} \quad$ : jumlah state pada matrik probabilitas transisi state (A)

$n_{O_{i}} \quad$ : jumlah observer $k$ yang bergantung pada state $i$.

$n_{a_{i j}} \quad$ : jumlah banyaknya $a_{i j}$ yang bernilai lebih dari 0 .

\section{HASIL UJI COBA}

Penelitian ini menggunakan data studi kasus yang merupakan modifikasi dari data penanganan ulasan jurnal.

Data studi kasus ini diambil dari event log Handling for $A$ Journal pada website http://www.processmining.org/. Data studi kasus terdiri dari 100 trace dimana 20 trace digunakan sebagai event log lampau (data training) dan 80 trace digunakan sebagai streaming event log (data testing). Setiap nama aktivitas diinisialisasi dengan abjad dan aktivitas pada streaming event log disimulasikan berjalan dalam kurun waktu 0,5 detik.

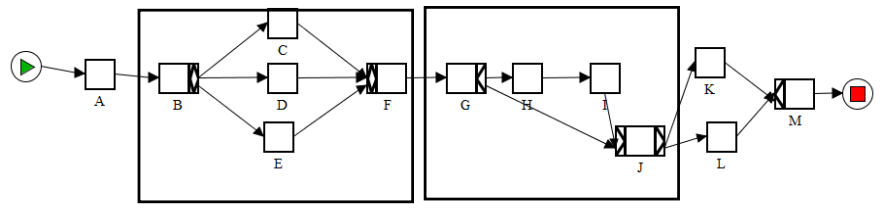

Gambar 4. Model Proses dari Streaming Event log

Pemodifikasian dilakukan dengan mengembangkan proses pada model proses dari event log lampau. Model proses dari event log lampau ditunjukkan pada Gambar 3 sedangkan alur proses dalam kotak pada Gambar 4 menunjukkan pengembangan proses pada streaming event log.

Pemodifikasian dilakukan dengan mengembangkan proses pada model proses dari event log lampau. Model proses dari event log lampau ditunjukkan pada Gambar 3 sedangkan alur proses dalam kotak pada Gambar 4 menunjukkan kejadian pengembangan proses pada streaming event log.

Pada kotak pertama Gambar 4, dapat dilihat bahwa pengembangan proses dilakukan dengan penambahan aktivitas C,D,E diantara alur proses aktivitas B ke aktivitas F sehingga terdapat relasi tambahan yaitu relasi OR. Selain itu, terdapat pengembangan proses lainnya yaitu penambahan aktivitas $\mathrm{H}$ dan I diantara alur proses aktivitas G ke aktivitas J. Hal itu mengakibatkan munculnya relasi baru yaitu XOR.

Penelitian ini melakukan uji coba sebanyak tiga kali, yaitu pembentukan model proses menggunakan algoritma yang memanfaatkan Model Markov Tersembunyi dan algoritma pembanding, Online Heuristic Miner setiap 5 detik, setiap 10 detik dan setiap 15 detik. Variasi uji coba tersebut digunakan untuk memunculkan variasi data masukan dalam pembentukan model proses. Setiap model proses yang dihasilkan akan diukur kualitasnya dari sisi fitness, presisi, generalisasi dan simplicity. Hasil kualitas model proses tersebut ditunjukan pada Tabel 6.

\section{KESIMPULAN/RINGKASAN}

Penelitian ini memaparkan algoritma yang digunakan untuk menghasilkan model proses dari streaming event log dengan memanfaatkan Model Markov Tersembunyi.

Algoritma yang memanfaatkan Model Markov Tersembunyi memiliki beberapa tahapan. Tahapan pertama adalah pembentukan Model Markov Tersembunyi dari event log lampau dengan menggunakan modifikasi metode BaumWelch. Pemodifikasian metode Baum-welch adalah penambahan aturan penentuan parameter Model Markov Tersembunyi sebelum dilakukan metode Baum-welch. Tahapan kedua adalah perbaikan incomplete trace dari streaming event log dengan menggunakan modifikasi metode Viterbi dan metode Backward. Pemodifikasian metode adalah penambahan aturan untuk menanggulangi aktivitas yang belum diinisialisasi pada Model Markov Tersembunyi serta penambahan pencarian observer sebagai pengganti aktivitas terpotong pada incomplete trace. Tahapan ketiga adalah pembentukan Model Markov Tersembunyi dari streaming event log yang telah diperbaiki dan tahapan terakhir adalah pembentukan model proses dengan menggunakan Model Markov Tersembunyi dari streaming event log dan metode 
pembentukan proses. Metode pembentukan proses terdiri dari peraturan serta rumus yang merupakan gagasan penelitian.

Tabel 6.

Hasil kualitas model proses dari sisi fitness, presisi, generalisasi dan simplicity

\begin{tabular}{c|c|c|c|c|c}
\hline \hline \multirow{2}{*}{ Metode } & Uji Coba & Total & Total & Total & Total \\
& & $Q_{f}$ & $Q_{p}$ & $Q_{g}$ & $Q_{s}$ \\
\hline Algoritma yang & 5 detik & 0,982 & 0,448 & 0,887 & 0,947 \\
\cline { 2 - 6 } memanfaatkan & 10 detik & 0,983 & 0,435 & 0,862 & 0,94 \\
\cline { 2 - 6 } $\begin{array}{c}\text { Model Markov } \\
\text { Tersembunyi }\end{array}$ & 15 detik & 0,985 & 0,553 & 0,861 & 0,937 \\
\cline { 2 - 6 } & Rata-rata & 0,983 & 0,479 & 0,87 & 0,941 \\
\hline \multirow{3}{*}{$\begin{array}{c}\text { Online Heuristic } \\
\text { Miner }\end{array}$} & 5 detik & 0,912 & 0,406 & 0,88 & 0,927 \\
\cline { 2 - 6 } & 10 detik & 0,885 & 0,375 & 0,851 & 0,925 \\
\cline { 2 - 6 } & 15 detik & 0,839 & 0,461 & 0,854 & 0,92 \\
\cline { 2 - 6 } & Rata-rata & 0,879 & 0,414 & 0,862 & 0,924 \\
\hline \hline
\end{tabular}

\section{dimana:}

Total $Q_{f}$ : nilai rata-rata dari kualitas sisi fitness semua model proses pada masing-masing uji coba.

Total $Q_{p}$ : nilai rata-rata dari kualitas sisi presisi semua model proses pada masing-masing uji coba.

Total $Q_{g}$ : nilai rata-rata dari kualitas sisi generalisasi semua model proses pada masing-masing uji coba.

Total $Q_{s}$ : nilai rata-rata dari kualitas sisi generalisasi semua model proses pada masing-masing uji coba.

Rata-rata : nilai rata-rata dari kualitas model proses untuk masing-masing sisi kualitas pada uji coba dengan jangka waktu antar pembentukan model proses selama 5 detik, 10 detik dan 15 detik.

Berdasarkan nilai rata-rata pada Tabel 6 , hasil uji coba menunjukkan bahwa nilai kualitas dari sisi fitness, presisi, generalisasi dan simplicity model proses yang dibentuk oleh algoritma yang memanfaatkan Model Markov Tersembunyi lebih tinggi dibandingkan model proses yang dibentuk oleh algoritma Online Heuristic Miner. Hal tersebut membuktikan bahwa perbaikan incomplete trace pada algoritma yang memanfaatkan Model Markov Tersembunyi mengakibatkan kualitas model proses yang dibentuk oleh algoritma tersebut lebih baik dibandingkan kualitas model proses dari algoritma Online Heuristic Miner.

\section{UCAPAN TERIMA KASIH}

Penulis K.R.S mengucapkan terima kasih kepada Tuhan Yang Maha Esa, Orang Tua, Bapak Dosen Pembimbing, Bapak Ibu Dosen Teknik Informatika ITS serta Teman-Teman Teknik Infomatika ITS yang mendukung penelitian ini.

\section{DAFTAR PUSTAKA}

[1] W. M. P. van der Aalst, Process Mining - Discovery, Conformance and Enhancement of Business Processes, Schleiden: Springer (2010).

[2] A. S. Burattin dan W. M. P. van der Aalst, "Heuristic Miners for Streaming Event Data," ArXiv CoRR, 2012.

[3] K. Audhkhasi, O. Osoba dan B. Kosko, "Noisy hidden Markov models for speech recognition," dalam Neural Networks (IJCNN), The 2013 International Joint Conference, 2013.

[4] A. C. Testa, J. Hane, S. Ellwood dan R. P. Oliver, "Coding Quarry: highly accurate hidden Markov model gene prediction in fungal genomes using RNA-seq transcripts," BMC genomics, vol. 16, no. 1, p. 1, 2015.
[5] M. R. Hassan, K. Ramamohanarao, J. Rahman dan M. M. Hossain, "A HMM-based adptive fuzzy inference system for stock market forecasting," Neurocomputing, vol. 104, pp. 10-25, 2013.

[6] R. Sarno and K. R. Sungkono, "Hidden Markov Model for Process Mining of Parallel Business Processes," International Review on Computers and Software (IRECOS), vol. 11, no. 4, pp. 290-300, 2016.

[7] A. Tenyakov, "Estimation of Hidden Markov Models and Their Applications in Finance," Electronic Thesis and Dissertation Repository, 2014.

[8] S. De Cnudde, J. Claes, dan G. Poels, "Improving the quality of the Heuristics Miner in ProM 6.2," Expert Systems with Applications, vol. 41, no. 17 , pp. 7678-7690, 2014.

[9] C. A. M. Buijs, B. F. van Dongen dan W. M. P. van der Aalst, "On The Role of Fitness, Precision, Generalization and Simplicity in Process Discovery," dalam Lecture Notes in Computer Science, Berlin, SpringerVerlag, 2012, pp. 305-322.

[10] R. A. Sutrisnowati, H. Bae, L. Dongha dan K. Minsoo, "Process Model Discovery based on Activity Lifespan," dalam International Conference on Technology Innovation and Industrial Management, Seoul, 2014.

[11] P. Dymarski, Hidden Markov Model, Theory and Application, India: InTech, 2011. 